\title{
Bortezomib and etoposide combinations exert synergistic effects on the human prostate cancer cell line PC-3
}

\author{
BEKIR ARAS $^{1}$ and AZMI YERLIKAYA ${ }^{2}$ \\ Departments of ${ }^{1}$ Urology and ${ }^{2}$ Medical Biology, Faculty of Medicine, Dumlupınar University, Kütahya 43100, Turkey \\ Received February 4, 2015; Accepted February 16, 2016
}

DOI: $10.3892 / 01.2016 .4340$

\begin{abstract}
Novel treatment modalities are urgently required for androgen-independent prostate cancer. In order to develop an alternative treatment for prostate cancer, the cytotoxic effects of the $26 \mathrm{~S}$ proteasome inhibitor bortezomib, either alone or in combination with the two commonly used chemotherapeutic agents irinotecan and etoposide, on the human prostate cancer cell line PC-3 were evaluated in the present study. The PC-3 cell line was maintained in Dulbecco's modified Eagle's medium with $10 \%$ fetal bovine serum and treated with various doses of bortezomib, irinotecan, etoposide or their combinations. The growth inhibitory and cytotoxic effects were determined by water-soluble tetrazolium (WST)-1 assay, 3-(4,5-dimethylthiazol-2-yl)-2,5-diphenyltetrazolium bromide (MTT) assay or iCELLigence system. The combination index values were determined by the Chou-Talalay method. The half maximal inhibitory concentration $\left(\mathrm{IC}_{50}\right)$ value of bortezomib on the PC-3 cell line was determined to be $53.4 \mathrm{nM}$ by WST-1 assay, whereas the $\mathrm{IC}_{50}$ values of irinotecan and etoposide were determined to be 2.1 and $26.5 \mu \mathrm{M}$, respectively. These results suggest that the $26 \mathrm{~S}$ proteasome inhibitor bortezomib is more potent, compared with irinotecan and etoposide, in the androgen-insensitive and tumor protein p53-null cell line PC-3. The combined effects of bortezomib+irinotecan and bortezomib+etoposide were also tested on PC-3 cells. The effect of bortezomib+irinotecan combination was not significantly different than that produced by either monotherapy, according to the results of iCELLigence system and MTT assay. However, $40 \mathrm{nM}$ bortezomib $+5 \mu \mathrm{M}$ etoposide or $40 \mathrm{nM}$ bortezomib $+20 \mu \mathrm{M}$ etoposide combinations were observed to be more effective than each drug tested alone. The results of the current study suggest that bortezomib and etoposide combination may be additionally evaluated in clinical trials for the treatment of hormone-refractory prostate cancer.
\end{abstract}

Correspondence to: Dr Azmi Yerlikaya, Department of Medical Biology, Faculty of Medicine, Dumlupınar University, Evliya Çelebi Yerleşkesi, Kütahya 43100, Turkey

E-mail: azmiyerlikaya@yahoo.com

Key words: bortezomib, cancer, etoposide, irinotecan, prostate

\section{Introduction}

Prostate cancer is the most common type of cancer diagnosed in men, and the second cause of cancer-associated mortalities in the USA and Western Europe $(1,2)$. By contrast, prostate adenocarcinoma rarely occurs in Japanese and Chinese men $(1,2)$. According to the statistical data established from the demographic records in the USA, 1 out of 6 men is diagnosed with prostate carcinoma during his lifetime (3), and $\sim 1 / 2$ of these patients experience the final stage of malignancy despite certain local treatment modalities, including radiotherapy and radical prostatectomy $(4,5)$. Currently, the suppression of androgenic hormones is the only effective systemic treatment approach during the advanced phase of prostate cancer $(6,7)$. However, the general outcome of this approach is not essentially curative, although $\sim 80 \%$ of the cases demonstrate objective or subjective responses to anti-androgenic therapy $(6,7)$. As a result, the disease becomes insensitive to the suppression approach during its course, and is then defined as hormone-refractory prostate carcinoma (HRPC) $(6,7)$. In the majority of cases that receive androgenic suppression treatment, HRPC develops in $1-4$ years $(6,7)$, depending on various prognostic factors, and the mean survival rate has been reported to be 12-18 months (8). By contrast, a minimal favorable effect on the mean survival rate of these patients has been reported with docetaxel, a derivative agent resembling taxol, which may suggest the beginning of a novel era for the treatment of HRPC $(9,10)$. In regards to the possibility of total cure, chemotherapy is far from clinical expectations $(9,10)$. Thus, no current standardized treatment exists for HRPC, and ongoing research studies on this field are currently being conducted $(9,10)$. The ubiquitin proteasome pathway may aid the investigation or discovery of novel targets for cancer treatment $(11,12)$. Bortezomib is a highly specific and reversible inhibitor of the 26S proteasome that has been approved for the treatment of multiple myeloma $(11,12)$. Although, bortezomib has demonstrated strong antitumor activity in clinical settings against hematological malignancies (11), the drug has not been approved for the treatment of solid tumors to date. Bortezomib was previously indicated to cause apoptosis and growth inhibition through tumor protein p53 (p53)-dependent and p53-independent mechanisms in a number of cells in vitro $(13,14)$. In the present study, the effect of bortezomib on the androgen-independent and p53-deficient cell line PC-3, alone and in combination with chemotherapeutic agents 
such as irinotecan (an inhibitor of topoisomerase I, a nuclear enzyme maintaining the DNA structure) and etoposide (a topoisomerase II inhibitor) were investigated. The combination of bortezomib with etoposide produced synergistic effects at several doses, and may be tested in clinical settings against prostate cancer as an alternative treatment in the future.

\section{Materials and methods}

Materials. Dulbecco's modified Eagle's medium (DMEM) cell culture media, fetal bovine serum (FBS), trypsin, penicillin and streptomycin were obtained from Sigma-Aldrich (St. Louis, MO USA). Bortezomib was provided by Dr Engin Ulukaya (Uludağ University, Bursa, Turkey), and PC-3 cells were provided by Dr Serap Kuruca Erdem (İstanbul University, İstanbul, Turkey). Water-soluble tetrazolium (WST)-1 cell proliferation reagent was purchased from Roche Diagnostics GmbH (Mannheim, Germany). All other reagents were purchased from Sigma-Aldrich, unless otherwise stated.

Cell culture and maintenance. The human prostate cancer cell line used in the present study, PC-3, was cultured in DMEM containing $4.5 \mathrm{~g} / \mathrm{l}$ glucose, $0.375 \%$ sodium bicarbonate, $100 \mu \mathrm{g} / \mathrm{ml}$ streptomycin and $100 \mathrm{U} / \mathrm{ml}$ penicillin. The medium was supplemented with $10 \%$ FBS. Stock cultures were maintained in $25-\mathrm{cm}^{2}$ flasks (Corning Incorporated, Corning, NY, USA). Cells were grown in 96-well cell culture plates (Corning Incorporated), and subcultured or seeded at $\sim 70 \%$ confluence for subsequent experiments (13).

WST-1 cell proliferation assay. PC-3 prostate cancer cells were seeded at 1,000 cells/well in 96-well plates, and allowed to attach to the wells for $24 \mathrm{~h}$. Cells were then treated with various concentrations of bortezomib $(1 \mathrm{nM}, 10 \mathrm{nM}, 100 \mathrm{nM}$, $500 \mathrm{nM}, 1 \mu \mathrm{M}, 10 \mu \mathrm{M}, 50 \mu \mathrm{M}$ and $100 \mu \mathrm{M})$, etoposide (100 nM, $500 \mathrm{nM}, 1 \mu \mathrm{M}, 10 \mu \mathrm{M}, 50 \mu \mathrm{M}$ and $100 \mu \mathrm{M})$ and irinotecan (100 nM, $500 \mathrm{nM}, 1 \mu \mathrm{M}, 10 \mu \mathrm{M}, 50 \mu \mathrm{M}$ and $100 \mu \mathrm{M}$ ) for $24 \mathrm{~h}$. Following treatment, the medium was replaced with DMEM containing $0.5 \%$ FBS and $10 \%$ WST-1. Cells were incubated with WST-1 for $1 \mathrm{~h}$ at $5 \% \mathrm{CO}_{2}$ in an incubator, and the absorbance of each sample was next recorded with an enzyme-linked immunosorbent assay reader (RT-21000; Rayto Life and Analytical Sciences Co., Ltd., Shenzhen, China) using 450 and 630-nm filters as the reference filters.

\section{3-(4,5-dimethylthiazol-2-yl)-2,5-diphenyltetrazolium}

bromide (MTT)-based cytotoxicity assay. A total of 50,000 PC-3 cells were seeded in each $35 \times 10 \mathrm{~mm}$ plate. When cells were in the logarithmic phase of the growth curve (following $24 \mathrm{~h}$ of seeding), the cells were treated with bortezomib alone $(10 \mathrm{nM}$ or $40 \mathrm{nM})$, irinotecan alone $(100 \mathrm{nM}$, $500 \mathrm{nM}$ or $2 \mu \mathrm{M})$, etoposide alone $(5 \mu \mathrm{M}$ or $20 \mu \mathrm{M})$ or with a combination of the above drugs for $48 \mathrm{~h}$. Following exposure to the inhibitor, cells were treated for $2 \mathrm{~h}$ with DMEM containing $0.5 \% \mathrm{FBS}$ and $0.5 \mathrm{mg} / \mathrm{ml} \mathrm{MTT}$ at $37^{\circ} \mathrm{C}$ with $5 \%$ $\mathrm{CO}_{2}$. Following incubation, cells were lysed with $3 \%$ sodium dodecyl sulfate (SDS; $200 \mu \mathrm{l}$ ) plus $1 \mathrm{ml} 40 \mathrm{mM} \mathrm{HCl}$ /isopropanol for $15 \mathrm{~min}$. The homogenate was diluted 1:10 with the same solution used to lyse the cell $(200 \mu 13 \%$ SDS plus $1 \mathrm{ml} 40 \mathrm{mM} \mathrm{HCl}$ /isopropanol), and the absorbance of each sample was recorded at $570 \mathrm{~nm}$ with a SmartSpec Plus spectrophotometer (Bio-Rad Laboratories, Inc., Hercules, CA, USA) $(13,15)$.

iCELLigence system. Following resistor plate verification, $150 \mu \mathrm{l}$ cell culture medium (DMEM with $10 \%$ FBS) was added to each E-Plate L8 well (ACEA Biosciences, San Diego, CA, USA) and incubated at room temperature for $30 \mathrm{~min}$. The E-Plates were then inserted into the RTCA iCELLigence instrument (ACEA Biosciences) for background measurement. Subsequently, 12,500 PC-3 cells were seeded in each E-Plate L8 well in a final volume of $500 \mu \mathrm{l}$. Following $24 \mathrm{~h}$ of seeding, cells were treated with bortezomib alone, irinotecan alone or in combination for approximately $96 \mathrm{~h}$. The cell index, which is a measure of the relative change in electrical impedance to account for the cell status, was monitored every hour.

DNA fragmentation. A total of 200,000 PC-3 cells were seeded in 60x15-mm sterile petri dishes. Subsequently, cells in the logarithmic phase of the growth curve were treated with $10 \mathrm{nM}$ bortezomib, $40 \mathrm{nM}$ bortezomib, $5 \mu \mathrm{M}$ etoposide, $20 \mu \mathrm{M}$ etoposide or in combination $(10 \mathrm{nM}$ bortezomib $+5 \mu \mathrm{M}$ etoposide; $10 \mathrm{nM}$ bortezomib+20 $\mu \mathrm{M}$ etoposide; $40 \mathrm{nM}$ bortezomib $+5 \mu \mathrm{M}$ etoposide; and $40 \mathrm{nM}$ bortezomib $+20 \mu \mathrm{M}$ etoposide) for $48 \mathrm{~h}$. Control cells were treated with isotonic solution. Following treatment, cells were washed with $1 \mathrm{ml}$ phosphate-buffered saline (PBS; $8 \mathrm{~g} \mathrm{NaCI}, 0.2 \mathrm{~g} \mathrm{KCI}, 1.44 \mathrm{~g}$ $\mathrm{Na}_{2} \mathrm{HPO}_{4}$ and $0.24 \mathrm{~g} \mathrm{KH}_{2} \mathrm{PO}_{4}$, and then resuspended in $200 \mu \mathrm{l}$ PBS. DNA was then isolated using the Apoptotic DNA-Ladder kit (Roche Diagnostics $\mathrm{GmbH}$ ), according to the manufacturer's protocol. Equal amounts of DNA $(2 \mu \mathrm{g})$ from each sample were separated by $1.5 \%$ agarose (Vivantis Technologies Sdn. Bhd., Selangor Darul Ehsan, Malaysia) gel electrophoresis at $80 \mathrm{~V}$ for $2 \mathrm{~h}$. DNA was visualized by ethidium bromide staining under ultraviolet light, and the image was recorded using a Canon PowerShot G2 digital camera (Canon, Inc., Tokyo, Japan) and RemoteCapture 2.2 software. GelQuant. NET software (biochemlabsolutions.com/GelQuant-NET. html) was used for quantification of images.

Statistical analyses and combination index (CI) determination. Data were analyzed and plotted with GraphPad Prism 3.03 software (GraphPad Software, Inc., La Jolla, CA, USA). To determine the $\mathrm{IC}_{50}$ values of each inhibitor, a sigmoid-dose response curve was fitted to the data using nonlinear regression in GraphPad Prism 3.03 software. The statistical differences between the samples were evaluated by one-way analysis of variance, and the Bonferroni test was used for multiple comparisons. $\mathrm{P}<0.05$ was considered to indicate a statistically significant difference. The sample number (n) for each drug concentration varied between 2 and 6 , and the results are presented as the mean \pm standard error or deviation of the mean as stated in each figure legend. To analyze the effect of non-constant ratios of combinations of bortezomib and etoposide, CalcuSyn software version 1.0 (Biosoft, Ferguson, MO, USA) was used. The results of MTT assay were expressed as the fraction of cells treated with bortezomib or etoposide alone or in combination. The CI plot was then obtained, according to the Chou-Talalay method (16). 
A

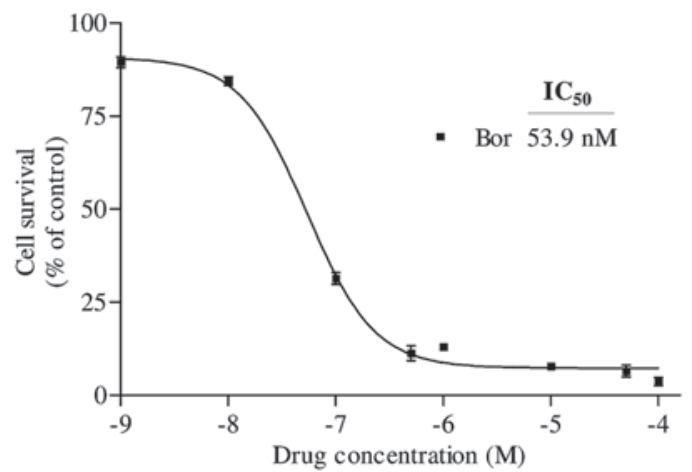

B

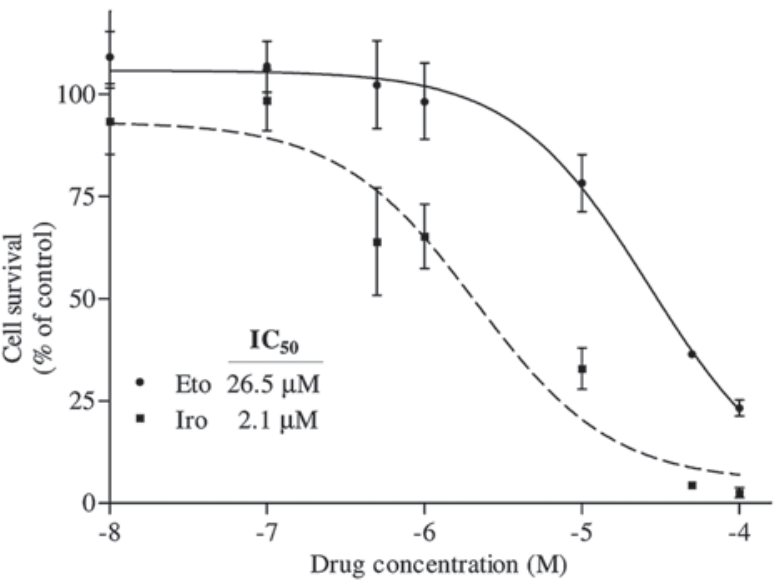

Figure 1. (A) Determination of the $\mathrm{IC}_{50}$ value of Bor on PC-3 cells. Cells were seeded in 96-well enzyme-linked immunosorbent assay plates and treated with $1 \mathrm{nM}, 10 \mathrm{nM}, 100 \mathrm{nM}, 500 \mathrm{nM}, 1 \mu \mathrm{M}, 10 \mu \mathrm{M}, 50 \mu \mathrm{M}$ and $100 \mu \mathrm{M}$ Bor for $24 \mathrm{~h}$. Following treatment, the percentage of cell survival was determined by water-soluble tetrazolium- 1 assay. The $\mathrm{IC}_{50}$ value of Bor was determined by fitting a sigmoidal dose-response curve to the data, using the GraphPad Prism 3.03 program. (B) Determination of the $\mathrm{IC}_{50}$ values of Iro and Eto on PC-3 cells. Cells were treated with various concentrations of Eto and Iro $(100 \mathrm{nM}, 500 \mathrm{nM}, 1 \mu \mathrm{M}, 10 \mu \mathrm{M}, 50 \mu \mathrm{M}$ and $100 \mu \mathrm{M})$ for $24 \mathrm{~h}$, and the $\mathrm{IC}_{50}$ values were similarly determined by analyzing the data with GraphPad Prism 3.03. The $\mathrm{X}$ axes in each graph is presented as $\log 10$ values, and the data are plotted as the mean \pm standard error. $\mathrm{IC}_{50}$, half maximal inhibitory concentration; Bor, bortezomib; Iro, irinotecan; Eto, etoposide.

\section{Results}

The growth of early prostate cancer cells requires $5 \alpha$-dihydrotestosterone; therefore, these cells are described as androgen-dependent (1). Since prostate cancer cells require androgen for growth, patients with prostate cancer are usually treated with hormonal intervention (1). However, following a period of remission, the prostate cancer recurs, and these cancer cells then become androgen-independent (1). In order to develop novel treatment strategies for prostate cancer, the present study tested the effect of the highly specific $26 \mathrm{~S}$ proteasome inhibitor bortezomib, either alone or in combination with irinotecan or etoposide, on PC-3 prostate cancer cells. As represented in Fig. 1A, PC-3 prostate cancer cells were observed to be highly sensitive to bortezomib following $24 \mathrm{~h}$ of treatment with this drug, whose $\mathrm{IC}_{50}$ value was determined to be $53.9 \mathrm{nM}$. The effects of irinotecan and etoposide on PC-3 cells were also examined following a period of 24-h incubation. $\mathrm{The} \mathrm{IC}_{50}$ values of irinotecan and etoposide were calculated to be 2.1 and $26.5 \mu \mathrm{M}$, respectively (Fig. 1B).
The combined effect of bortezomib and irinotecan on the PC-3 cell line was then examined with the iCELLigence system, an impedance-based system used for label-free and real-time monitoring of cytotoxicity. Based on the $\mathrm{IC}_{50}$ values obtained, the cells were treated with $10 \mathrm{nM}$ bortezomib, $100 \mathrm{nM}$ irinotecan, $500 \mathrm{nM}$ irinotecan or $2 \mu \mathrm{M}$ irinotecan, alone or in combination. Contrary to what it was expected, none of the above treatments caused significant cytotoxicity, according to the results of iCELLigence system analysis (Fig. 2). This phenomenon was hypothesized to be partly due to the enlargement of cell morphology following treatment with the aforementioned drugs as determined by visualization of E-plates under an inverted microscope (AE21; Motic Europe, Barcelona, Spain) (data not shown), which may consequently cause an increase in impedance despite the low cell number.

To confirm whether the bortezomib+irinotecan combination is more cytotoxic than the corresponding monotherapies, PC-3 cells were treated with the same concentrations used for of iCELLigence system, and tested by MTT assay. The iCELLigence data revealed that the doubling time of PC-3 prostate cancer cells under the experimental conditions used (cells were seeded at a density of 12,500 cells/E-Plate L8 well) was $44.8 \pm 3.8 \mathrm{~h}$. Therefore, cells were treated for $48 \mathrm{~h}$ with the aforementioned concentrations of drugs. As indicated in Fig. 3, only $2 \mu \mathrm{M}$ irinotecan induced significant cytotoxicity as compared to the control $(\mathrm{P}<0.05)$. However, $10 \mathrm{nM}$ bortezomib was combined with three different concentrations of irinotecan $(100 \mathrm{nM}, 500 \mathrm{nM}$ and $2 \mu \mathrm{M})$, and resulted in no significant enhancement of cytotoxicity compared with each treatment alone (Fig. 3), which is in agreement with the data obtained using the iCELLigence system.

The effects of two concentrations of bortezomib in combination with two concentrations of etoposide were also investigated by MTT assay. Cells were treated for $48 \mathrm{~h}$ with doses selected based on the aforementioned $\mathrm{IC}_{50}$ data. As shown in Fig. 4A, the effect of $40 \mathrm{nM}$ bortezomib in combination with $5 \mu \mathrm{M}$ etoposide was significantly different to that of $10 \mathrm{nM}$ bortezomib alone $(\mathrm{P}<0.001)$ and $5 \mu \mathrm{M}$ etoposide alone $(\mathrm{P}<0.001)$. Similarly, the effects of combining $40 \mathrm{nM}$ bortezomib with $20 \mu \mathrm{M}$ etoposide differed significantly, compared with $40 \mathrm{nM}$ bortezomib-alone treated cells $(\mathrm{P}<0.001)$ and $20 \mu \mathrm{M}$ etoposide-alone treated cells $(\mathrm{P}<0.001)$. In addition, the effect of $40 \mathrm{nM}$ bortezomib $+20 \mu \mathrm{M}$ etoposide combination was significantly different, compared with that of $40 \mathrm{nM}$ bortezomib $+5 \mu \mathrm{M}$ etoposide treatment $(\mathrm{P}<0.05)$. Analysis of DNA fragmentation also corroborated the results of the MTT assay. As shown in Fig. 4B and C, the $40 \mathrm{nM}$ bortezomib $+5 \mu \mathrm{M}$ etoposide combination resulted in a $\sim 2.8$-fold increase in DNA fragmentation (evaluated by the level of smearing), compared with $40 \mathrm{nM}$ bortezomib-treated cells, and in a 1.8-fold increase, compared with $5 \mu \mathrm{M}$ etoposide-treated cells. Similarly, the $40 \mathrm{nM}$ bortezomib $+20 \mu \mathrm{M}$ etoposide combination increased DNA fragmentation by $\sim 2.9$ fold, compared with $40 \mathrm{nM}$ bortezomib-treated cells, and by $\sim 1.4$ fold, compared with $20 \mu \mathrm{M}$ etoposide-treated cells.

In order to determine whether the effect of the bortezomib+etoposide combination was synergistic or additive, the CI values were calculated according to the Chou-Talalay method, using the data presented in Fig. 4A. The findings 


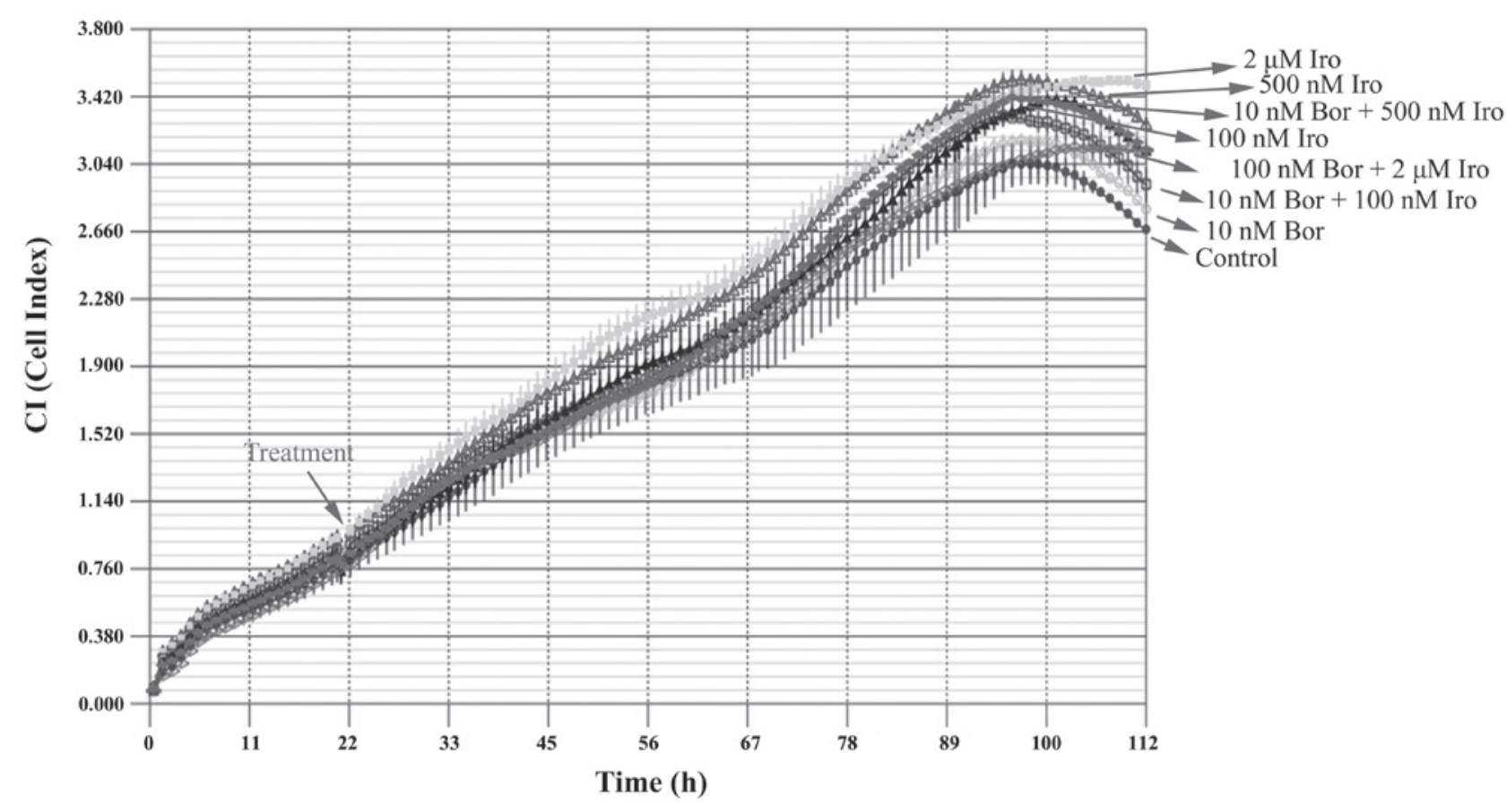

Figure 2. Effect of combination of Bor with Iro on PC-3 cells. A total of 12,500 PC-3 cells/well were seeded in E-Plates L8 and treated with $10 \mathrm{nM}$ Bor, $100 \mathrm{nM}$ Iro, $500 \mathrm{nM}$ Iro or $2 \mu \mathrm{M}$ Iro, alone or in combination ( $10 \mathrm{nM}$ Bor+100 nM Iro; $10 \mathrm{nM}$ Bor $+500 \mathrm{nM}$ Iro; and $10 \mathrm{nM}$ Bor $+2 \mu$ M Iro), for approximately $96 \mathrm{~h}$. The cell index was monitored every hour using iCELLigence system. The results are expressed as the mean \pm standard deviation $(\mathrm{n}=2)$. Bor, bortezomib; Iro, irinotecan

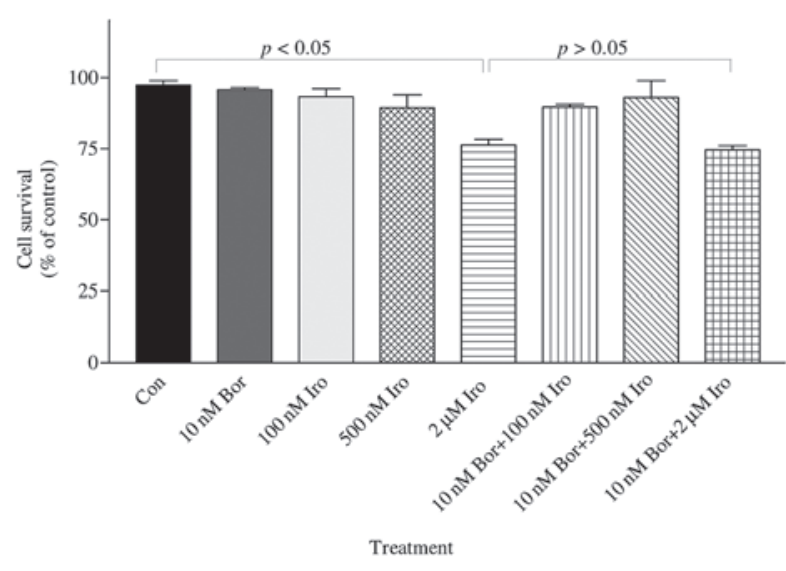

Figure 3. The combined effect of Bor and Iro on the survival of PC-3 cells was determined by MTT assay. PC-3 cells $(50,000)$ were seeded in 35x $10-\mathrm{mm}$ plates and treated with $10 \mathrm{nM}$ Bor, $100 \mathrm{nM}$ Iro, $500 \mathrm{nM}$ Iro and $2 \mu \mathrm{M}$ Iro, alone or in combination (10 nM Bor+100 nM Iro; $10 \mathrm{nM}$ Bor+500 nM Iro; and $10 \mathrm{nM}$ Bor $+2 \mu \mathrm{M}$ Iro), for $48 \mathrm{~h}$. The number of surviving cells was determined by MTT assay. The results are presented as the mean \pm standard error of the mean $(\mathrm{n}=3) .2 \mu \mathrm{M}$ irinotecan caused significant cytotoxicity as compared to the control $(\mathrm{P}<0.05)$; however, $2 \mu \mathrm{M}$ irinotecan did not cause significant cytotoxicity compared with $100 \mathrm{nM}$ irinotecan, $500 \mathrm{nM}$ irinotecan or $10 \mathrm{nM}$ bortezomib treatment. By contrast, $10 \mathrm{nM}$ bortezomib $+2 \mu \mathrm{M}$ irinotecan was significantly different compared with the control, but this combination was not significantly different than each drug treatment alone $(100 \mathrm{nM}$ irinotecan, $500 \mathrm{nM}$ irinotecan or $10 \mathrm{nM}$ bortezomib)(P>0.05). Con, control; Bor, bortezomib; Iro, irinotecan; MTT, 3-(4,5-dimethylthiazol-2-yl)-2,5-diphenyltetrazolium bromide.

indicated that treatment with the $40 \mathrm{nM}$ bortezomib $+5 \mu \mathrm{M}$ etoposide combination resulted in a CI value of 0.46 , and $40 \mathrm{nM}$ bortezomib $+20 \mu \mathrm{M}$ etoposide combination resulted in a CI value of 0.39 , indicating that these combinations cause synergistic effects on PC-3 cells.

\section{Discussion}

Bortezomib, the first proteasome inhibitor approved by the Food and Drug Administration for the treatment of multiple myeloma, induces apoptotic cell death in androgen-dependent and androgen-independent prostate cancer cell lines (17). In order to develop an alternative and novel treatment strategy for androgen-independent prostate cancer, the PC-3 cell line was treated with bortezomib, alone and in combination with irinotecan or etoposide, in the present study. $\mathrm{The} \mathrm{IC}_{50}$ value of bortezomib in PC-3 cells was determined to be $53.9 \mathrm{nM}$ following $24 \mathrm{~h}$ of treatment, which indicates that bortezomib is highly cytotoxic in this prostate cancer cell line. This result is in agreement with a number of previous studies performed on prostate cancer cells. For instance, Kiliccioglu et al (18) determined the $\mathrm{IC}_{50}$ value of bortezomib to be $30 \mathrm{nM}$, following 24-h treatment in LNCaP cells (bearing wild-type p53), and $50 \mathrm{nM}$ in PC-3 cells (which are p53-deficient). By contrast, Williams et al (19) indicated that the $\mathrm{IC}_{50}$ value of bortezomib was $\sim 10 \mathrm{nM}$ following $48 \mathrm{~h}$ of treatment in PC-3 cells. In another study, Sato et al (20) estimated the $\mathrm{IC}_{50}$ value of bortezomib in the PC-3 cell line to be $23 \mathrm{nM}$. Overall, these results suggest that prostate cancer cells are highly sensitive to bortezomib and that bortezomib is effective in p53-wild-type or p53-deficient prostate cancer cells.

In the present study, the $\mathrm{IC}_{50}$ values of etoposide $(26.5 \mu \mathrm{M})$ and irinotecan $(2.1 \mu \mathrm{M})$ in PC-3 cells were determined, and the effects of these drugs in combination with bortezomib were subsequently tested. The effect of irinotecan in combination with bortezomib was tested in the iCELLigence system; however, no significant cytotoxicity was observed in this real-time cell analysis system for $\leq 112 \mathrm{~h}$ of incubation. To the best of our knowledge, the combination of bortezomib+irinotecan has not 
A
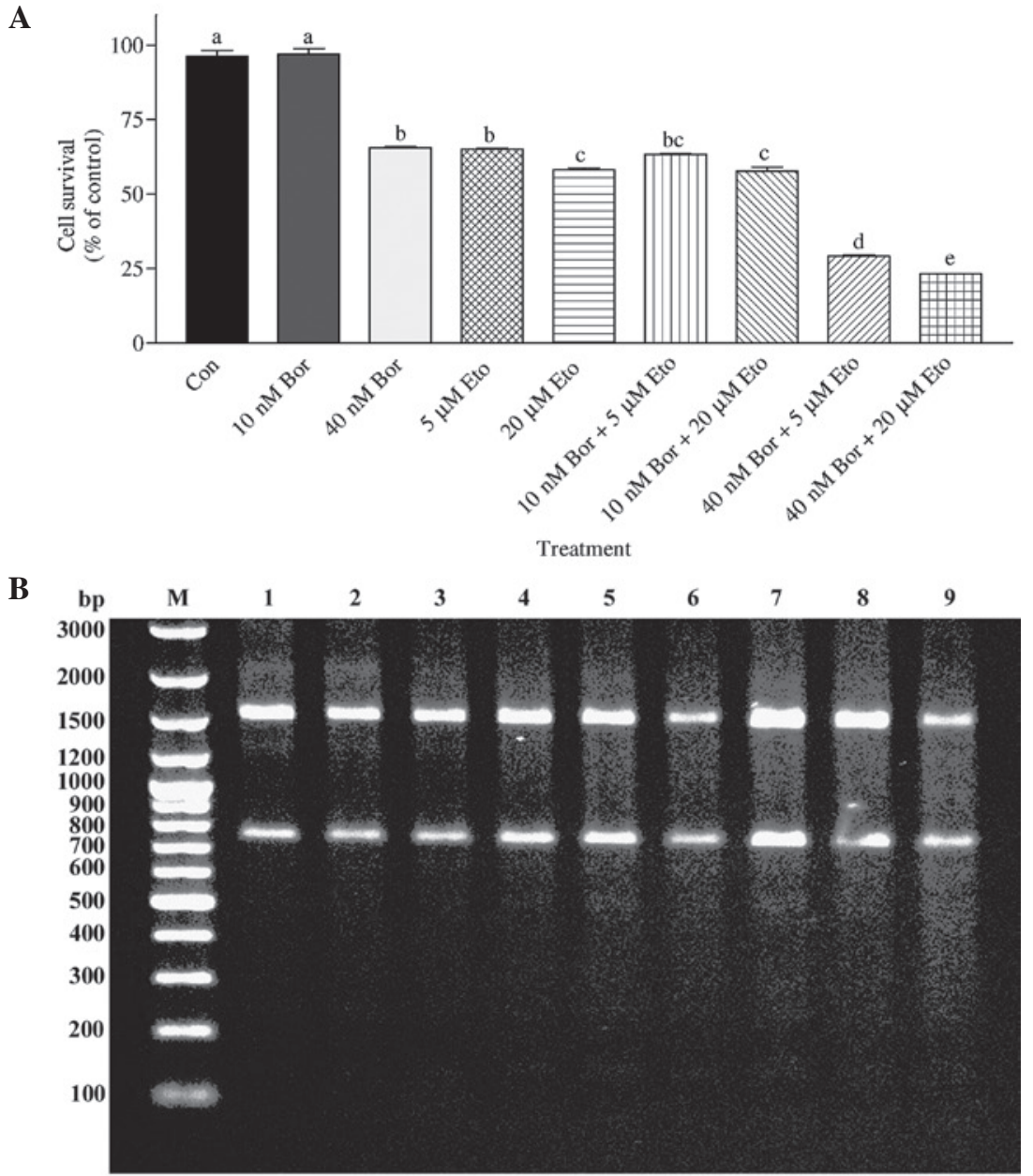

C

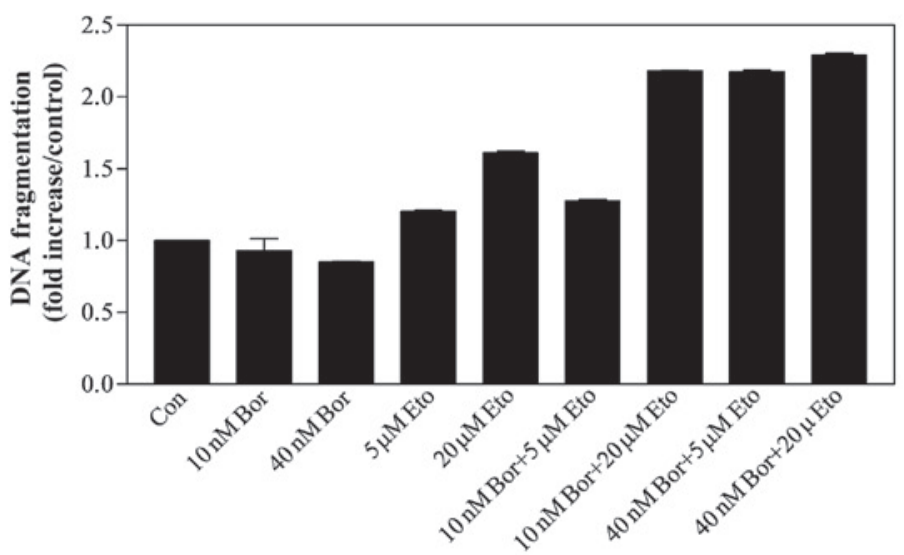

Treatment

Figure 4. (A) Determination of the effect of Bor and Eto by MTT assay. PC-3 cells were treated with $10 \mathrm{nM}$ Bor, $40 \mathrm{nM}$ Bor, $5 \mu \mathrm{M}$ Eto and $20 \mu \mathrm{M}$ Eto, alone or in combination (10 nM Bor $+5 \mu \mathrm{M}$ Eto; $10 \mathrm{nM}$ Bor+20 $\mu \mathrm{M}$ Eto; $40 \mathrm{nM}$ Bor $+5 \mu \mathrm{M}$ Eto; and $40 \mathrm{nM}$ Bor $+20 \mu \mathrm{M}$ Eto). The number of surviving cells was determined by MTT assay. The data are presented as the mean \pm standard error of the mean $(n=3)$. Means with the same letter are not significantly different from each other $(\mathrm{P}>0.05)$; means with different letters are significant different $(\mathrm{P}<0.05)$. (B) Determination of the combined effect of Bor and Eto treatment by DNA fragmentation analysis. PC-3 cells were treated with $10 \mathrm{nM}$ Bor, $40 \mathrm{nM}$ Bor, $5 \mu \mathrm{M}$ Eto and $20 \mu \mathrm{M}$ Eto, alone or in combination. DNA fragmentation was determined with the Roche Apoptotic DNA-Ladder kit, according to the manufacturer's protocol, using the 100 bp DNA ladder as a standard. M, marker; lane 1, control; lane 2, $10 \mathrm{nM}$ Bor; lane 3, $40 \mathrm{nM}$ Bor; lane 4, $5 \mu \mathrm{M}$ Eto; lane 5, $20 \mu \mathrm{M}$ Eto; lane 6, $10 \mathrm{nM}$ Bor+5 $\mu \mathrm{M}$ Eto; lane 7, $10 \mathrm{nM} \mathrm{Bor+20} \mu \mathrm{M}$ Eto; lane 8, $40 \mathrm{nM}$ Bor $+5 \mu \mathrm{M}$ Eto; and lane 9, $40 \mathrm{nM}$ Bor $+20 \mu \mathrm{M}$ Eto. (C) Quantification of the DNA smearing observed in panel B. Quantification was performed using the GelQuant.NET program. Con, control; Bor, bortezomib; Eto, etoposide; MTT, 3-(4,5-dimethylthiazol-2-yl)-2,5-diphenyltetrazolium bromide; bp, base pairs.

been previously tested on prostate cancer cells. In one of the rare studies performed on other types of cancer, Ocean et al (21) investigated the effect of bortezomib+irinotecan combination in patients with adenocarcinoma of gastroesophageal junction (GEJ) or stomach. However, bortezomib alone or in combination with irinotecan was not effective for the treatment of advanced adenocarcinoma of the GEJ or stomach (21). Similarly, in advanced colorectal carcinoma (CRC), bortezomib alone or in combination with irinotecan was ineffective in patients with relapsed or refractory CRC (22). 
The present study also examined the effect of the bortezomib+etoposide combination on PC-3 cells. Different doses of bortezomib (10 $\mathrm{nM}$ and $40 \mathrm{nM})$ were tested, either alone or in combination with various doses of etoposide (5 $\mu \mathrm{M}$ and $20 \mu \mathrm{M}$ ). Bortezomib at a dose close to its $\mathrm{IC}_{50}$ value was observed to be more cytotoxic on PC-3 cells when in combination with $5 \mu \mathrm{M}$ or $20 \mu \mathrm{M}$ etoposide. To the best of our knowledge, this bortezomib+etoposide combination has not been previously investigated on prostate cancer cells. However, the combination of bortezomib plus etoposide has been studied in children with relapsed, refractory or secondary acute myeloid leukemia (AML) (23). In those studies, bortezomib was reported to be tolerable in combination with chemotherapy regimens for relapsed pediatric AML, but the regimens $\left(1.3 \mathrm{mg} / \mathrm{m}^{2}\right.$ bortezomib and $100 \mathrm{mg} / \mathrm{m}^{2}$ etoposide) did not exceed the preset minimum response criteria to allow continued accrual (23). The dose of bortezomib combined with other chemotherapeutic drugs is hypothesized to be critical for obtaining effective treatment modalities (12), and the present results imply that doses close to the $\mathrm{IC}_{50}$ values of each inhibitor (bortezomib and etoposide) are crucial for exerting synergistic effects. Although both irinotecan and etoposide interfere with DNA replication through destabilizing DNA structure and causing DNA strand breaks $(24,25)$, only etoposide was observed to cause synergistic effects when in combination with $40 \mathrm{nM}$ bortezomib in the present study. Since various doses of irinotecan in combination with $40 \mathrm{nM}$ bortezomib were not tested in the present study, it is possible to hypothesize that irinotecan may also exert synergistic effects when in combination with $40 \mathrm{nM}$ bortezomib. The present authors are currently designing experiments to confirm the present results and to determine the combined effect of irinotecan+bortezomib.

In conclusion, the results of the present study suggest that targeting various intracellular pathways with two structurally and functionally different inhibitors (bortezomib, which inhibits the proteasome, and etoposide, which blocks the DNA topoisomerase activity) generated a more potent effect, compared with monotherapies. Therefore, the use of bortezomib, either alone or in combination with etoposide, requires additional studies in a clinical setting, and may be an alternative strategy for the treatment of androgen-independent prostate cancer.

\section{References}

1. Russell PJ and Kingsley EA: Human prostate cancer cell lines. Methods Mol Med 81: 21-39, 2003.

2. Whang PG, Gamradt SC, Gates JJ and Lieberman JR: Effects of the proteasome inhibitor bortezomib on osteolytic human prostate cancer cell metastases. Prostate Cancer Prostatic Dis 8: 327-334, 2005

3. Potosky AL, Miller BA, Albertsen PC and Kramer BS: The role of increasing detection in the rising incidence of prostate cancer. JAMA 273: 548-552, 1995.

4. Hanks GE, Krall JM, Hanlon AL, Asbell SO, Pilepich MV and Owen JB: Patterns of Care and RTOG studies in prostate cancer: Long-term survival, hazard rate observations, and possibilities of cure. Int J Radiat Oncol Biol Phys 28: 39-45, 1994.

5. Zincke H, Oesterling JE, Blute ML, Bergstralh EJ, Myers RP and Barrett DM: Long-term (15 years) results after radical prostatectomy for clinically localized (stage $\mathrm{T} 2 \mathrm{c}$ or lower) prostate cancer. J Urol 152: 1850-1857, 1994.

6. Crawford ED, Eisenberger MA, McLeod DG, Spaulding JT, Benson R, Dorr FA, Blumenstein BA, Davis MA and Goodman PJ: A controlled trial of leuprolide with and without flutamide in prostatic carcinoma. N Engl J Med 321: 419-424, 1989.
7. Eisenberger MA, Crawford ED, Wolf M, Blumenstein B McLeod DG, Benson R, Dorr FA, Benson M and Spaulding JT: Prognostic factors in stage D2 prostate cancer; important implications for future trials: Results of a cooperative intergroup study (INT.0036). The National Cancer Institute Intergroup Study \#0036. Semin Oncol 21: 613-619, 1994.

8. Newling DW, Denis L and Vermeylen K: Orchiectomy versus goserelin and flutamide in the treatment of newly diagnosed metastatic prostate cancer. Analysis of the criteria of evaluation used in the European Organization for Research and Treatment of Cancer - Genitourinary Group Study 30853. Cancer 72 (Suppl 12): 3793-3798, 1993.

9. Bracarda S, Logothetis C, Sternberg CN and Oudard S: Current and emerging treatment modalities for metastatic castration- resistant prostate cancer. BJU Int 107 (Suppl 2): 13-20, 2011.

10. Sartor O, Halstead M and Katz L: Improving outcomes with recent advances in chemotherapy for castrate-resistant prostate cancer. Clin Genitourin Cancer 8: 23-28, 2010.

11. Papandreou CN and Logothetis CJ: Bortezomib as a potential treatment for prostate cancer. Cancer Res 64: 5036-5043, 2004.

12. Yerlikaya A and Yöntem M: The significance of ubiquitin proteasome pathway in cancer development. Recent Patents Anticancer Drug Discov 8: 298-309, 2013.

13. Yerlikaya A and Erin N: Differential sensitivity of breast cancer and melanoma cells to proteasome inhibitor Velcade. Int J Mol Med 22: 817-823, 2008.

14. Yerlikaya A, Okur E and Ulukaya E: The p53-independent induction of apoptosis in breast cancer cells in response to proteasome inhibitor bortezomib. Tumour Biol 33: 1385-1392, 2012.

15. Freshney RI: Cytotoxicity. In: Culture of Animal Cells: A Manual of Basic Technique. 5th edition. John Wiley and Sons Inc., Hoboken, NJ, p359, 2005.

16. Pham LV, Tamayo AT, Li C, Bornmann W, Priebe W and Ford RJ: Degrasyn potentiates the antitumor effects of bortezomib in mantle cell lymphoma cells in vitro and in vivo: Therapeutic implications. Mol Cancer Ther 9: 2026-2036, 2010.

17. Adams J, Palombella VJ, Sausville EA, Johnson J, Destree A, Lazarus DD, Maas J, Pien CS, Prakash S and Elliott PJ: Proteasome inhibitors: A novel class of potent and effective antitumor agents. Cancer Res 59: 2615-2622, 1999.

18. Kiliccioglu I, Konac E, Varol N, Gurocak S and Yucel Bilen C: Apoptotic effects of proteasome and histone deacetylase inhibitors in prostate cancer cell lines. Genet Mol Res 13: 3721-3731, 2014.

19. Williams S, Pettaway C, Song R, Papandreou C, Logothetis C and McConkey DJ: Differential effects of the proteasome inhibitor bortezomib on apoptosis and angiogenesis in human prostate tumor xenografts. Mol Cancer Ther 2: 835-843, 2003.

20. Sato A, Asano T, Ito K and Asano T: Vorinostat and bortezomib synergistically cause ubiquitinated protein accumulation in prostate cancer cells. J Urol 188: 2410-2418, 2012.

21. Ocean AJ, Christos P, Sparano JA, Shah MA, Yantiss RK, Cheng J, Lin J, Papetti M, Matulich D, Schnoll-Sussman F, et al: Phase II trial of bortezomib alone or in combination with irinotecan in patients with adenocarcinoma of the gastroesophageal junction or stomach. Invest New Drugs 32: 542-548, 2014.

22. Kozuch PS, Rocha-Lima CM, Dragovich T, Hochster H, O'Neil BH, Atiq OT, Pipas JM, Ryan DP and Lenz HJ: Bortezomib with or without irinotecan in relapsed or refractory colorectal cancer: Results from a randomized phase II study. J Clin Oncol 26: 2320-2326, 2008.

23. Horton TM, Perentesis JP, Gamis AS, Alonzo TA, Gerbing RB, Ballard J, Adlard K, Howard DS, Smith FO, Jenkins G, et al: A Phase 2 study of bortezomib combined with either idarubicin/cytarabine or cytarabine/etoposidee in children with relapsed,refractory or secondary acute myeloid leukemia: A report from the Children's Oncology Group. Pediatr Blood Cancer 61: 1754-1760, 2014.

24. Petitprez A, Poindessous V, Ouaret D, Regairaz M, Bastian G, Guérin E, Escargueil AE and Larsen A: Acquired irinotecan resistance is accompanied by stable modifications of cell cycle dynamics independent of MSI status. Int J Oncol 42: 1644-1653, 2013.

25. Groh T, Hrabeta J, Khalil MA, Doktorova H, Eckschlager T and Stiborova M: The synergistic effects of DNA-damaging drugs cisplatin and etoposide with a histone deacetylase inhibitor valproate in high-risk neuroblastoma cells. Int J Oncol 47: 343-352, 2015. 